\title{
La tradición de calidad educativa del Programa de Estomatología
}

\author{
The tradition of the educational quality of the Stomatology Program
}

Desde sus orígenes, la Facultad de Estomatología de la Universidad Peruana Cayetano Heredia inicia sus actividades educativas con una visión compartida de formar a profesionales estomatólogos que contribuyan en la mejora de la salud de la población. Un currículo innovador que conjugó clínicas integrales, internado en ámbito hospitalario en el cual se forma parte del equipo de salud, internado rural que permitió al estudiante enfrentar la realidad del campo en nuestro país y un puñado de profesores con capacitación internacional y altamente comprometidos, fueron una fórmula perfecta para este gran proyecto.

El programa de Estomatología se consolidó como referente para la enseñanza de la profesión, marcando una ruta en la educación de calidad, la cual fue emulada por varias instituciones educativas a nivel nacional e internacional, convirtiéndonos en una institución de referencia en esta parte del mundo.

Hace veinte años, antes de la creación del Sistema Nacional de Evaluación, Acreditación y Certificación de la Calidad Educativa del Perú, la Facultad decide realizar el proceso de autoevaluación como un mecanismo de mejora constante. Esta capacidad de autorregulación le permite marcar una ruta de calidad para la profesión odontológica del país, convirtiéndose en el primer programa con Acreditación Internacional otorgado por el Consejo Nacional de Acreditación de Colombia y el primer programa del país en obtener la Acreditación Nacional del Consejo Nacional de Evaluación, Acreditación y Certificación de la Calidad de la Educación Superior Universitaria - CONEAU.

Siempre a la vanguardia de la enseñanza, como desde un inicio, hemos dedicado tiempo a proyectarnos en el futuro y seguir mejorando la educación de nuestros estudiantes. Ejemplo de esta visión, es el centro de simulación en realidad virtual para la enseñanza odontológica, con equipos de última generación, estrategia educativa gestada para la mejora de la enseñanza y que hoy, se convierte en una respuesta apropiada al contexto actual para asegurar el logro de las competencias necesarias que hoy requiere un cirujano-dentista.

Toca hoy celebrar un logro más: la Acreditación Internacional otorgada por el Instituto Internacional para el Aseguramiento de la Calidad del Centro Interuniversitario de Desarrollo IAC-CINDA, quienes evaluaron de manera rigurosa por varios meses nuestro programa educativo, otorgándonos la acreditación por cinco años, tiempo máximo establecido por el Instituto. La alineación del perfil, los mecanismos de evaluación del logro de las competencias, los mecanismos de evaluación docente, la infraestructura y equipamiento, así como la búsqueda de mejora continua, son las fortalezas que destaca tal decisión. 
Estamos seguros que tal reconocimiento será el estímulo para un trabajo participativo de los docentes, estudiantes, egresados y personal administrativo en los planes de mejora. La Facultad de Estomatología renueva así su compromiso con una educación de calidad, en alineación con la política institucional.

Milagros Carrasco Loyola ${ }^{1, a}$ 